\title{
The Relationship between Good Governance Administration and Service Quality at Na Yai Arm Sub-District Administrative Organization, Na Yai Arm District, Chantaburi Province, Thailand.
}

\author{
Asst.Prof.Dr. Pongsatean Luengalongkot \\ Faculty Member, Graduate School Of Public Administration, \\ Burapha University, 2014 \\ Pongsate@Hotmail.Com
}

\begin{abstract}
The objectives of this study include: 1) to study the level of good governance administration at Na Yai Arm Sub-District Administrative Organization, Na Yai Arm District, Chantaburi Province; 2) to study the level of service quality of $\mathrm{Na}$ Yai Arm Sub-District Administrative Organization and; 3) to study the relationship between good governance administration and service quality at $\mathrm{Na}$ Yai Arm Sub-District Administrative Organization. The population consisted of 2,946 heads of household who were registered in Na Yai Arm Sub-District Administrative Organization. The sample size was calculated by Taro Yamane's formula with a confidence level of $95 \%$. There were 352 participants used as a sample group who were selected by using a stratified random sampling technique. A questionnaire was used as the research instrument in this study. Statistics used to analyze data included frequency, percentage, mean, standard deviation, and Pearson Product Moment Correlation. The level of statistical significance was set at 0.01 . The results revealed that: The sample group reflected that good governance administration at Na Yai Arm Sub-District Administrative Organization was of a high level; The sample group revealed that the service quality of Na Yai Arm SubDistrict Administrative Organization was of a high level; There was a linear relationship between good governance administration and service quality of Na Yai Arm Sub-District Administrative Organization.
\end{abstract}

Keywords: Good Governance, Service Quality, Sub-District Administrative Organization

\section{Introduction}

The concept of good governance spread in Thailand from 1997, during the economic crisis in the country. The main problems were the decline in effectiveness of public administration, and economic and political decline. If the problems were not solved immediately and effectively, the country's society and economy could not be improved. Therefore, the cabinet assigned the Thailand Development Research Institute (TDRI) to conduct research and seek solutions for the economic crisis and to prevent the problems recurring. Subsequently, the Office of the Civil Service Commission was assigned by the cabinet to develop a memo about creating good public administration in accordance with the findings of the TDRI. Then it was proposed to the cabinet, and it was launched as a regulation of the Office of the Prime Minister on $22^{\text {nd }}$ May, 1999. After that, the regulations of the Office of the Prime Minister on creating good public administration was announced on $10^{\text {th }}$ August, 1999. It has been in effect since $11^{\text {st }}$ August, 1999. This was the beginning of the new public administration or good governance which influenced government offices and the private sector, including SubDistrict Administrative Organizations. The application of good governance of Sub-District Administrative Organizations will be beneficial for the organizations and citizens were also satisfied with the good service quality (Rochana, 2010). Hood (1991) has claimed that the new public management is important for the provision of public services to citizens by strongly focusing on providing services to citizens who are the public service's clients. The service quality concept was applied in Thai public management reform many years ago and it was applied as a 
tool to measure the competency and effectiveness of public service provision by public agencies (Crosby, 1979).

The Na Yai Arm Sub-District Administrative Organization has applied good governance policy in the organization in order to improve the work performance and achieve a high level of satisfaction from the citizens. The main problem in $\mathrm{Na}$ Yai Arm Sub-District Administrative Organization is cost effectiveness. There is no maximization of utilization of resource. Furthermore, they still address the different needs of people. Through the implementation of good governance, some problems, such as lack of budget, inadequate staff, and insufficient tools and equipment, were found. The management team of $\mathrm{Na}$ Yai Arm Sub-District Administrative Organization has solved these problems in order to meet the needs of the people. The researcher conducted the study on good governance and service quality by focusing on the level of good governance administration consisting of: rule of law, morality, transparency, participation, accountability, and cost-effectiveness (Good governance, 2013). Service quality of $\mathrm{Na}$ Yai Arm Sub- District Administrative Organization was measured using the concepts oftangibility, reliability, responsiveness, assuranceand empathy (Parasuraman, Zeithaml and Berry, 1988). In addition, the researcher hopes to reveal the relationship between good governance and service quality at $\mathrm{Na}$ Yai Arm Sub-District Administrative Organization. The results of the study will be useful guidelines in developing $\mathrm{Na}$ Yai Arm Sub-District Administrative Organization for better work performance and service quality.

\section{Objectives Of The Research}

1) To study the level of good governance administration at Na Yai Arm Sub- District Administrative Organization.

2) To study the level of service quality of $\mathrm{Na}$ Yai Arm Sub-District Administrative Organization.

3) To study the relationship between good governance administration and service quality at $\mathrm{Na}$ Yai Arm Sub-District Administrative Organization.

\section{Conceptual Framework.}

The conceptual framework consisted of these main ideas with an independent variableand dependent variable as shown in figure 1 (Adopted from Report of good governance (2013) and from Parasuraman, Zeithaml and Berry, 1988). 


\section{Figure 1: Conceptual Framework}

Independent Variable
Dependent Variable

\section{Good governance}

\section{Research Hypothesis}

There is a linear relationship between good governance administration and service quality at $\mathrm{Na}$ Yai Arm Sub-District Administrative Organization.

\section{Expected Benefit of This Study}

Identification of the relationship between work performance with good governance and service quality of Na Yai Arm Sub-District Administrative Organization.

\section{Research Methodology:}

The population was 2,946 heads of household who were registered in $\mathrm{Na}$ Yai Arm Sub-District Administrative Organization. The sample size was calculated by Taro Yamane's formula (Taro Yamane, 1973) with a confidence level of $95 \%$ (Chaleamphol Srihong,1999). There were 352 participants used as a sample group who were selected using stratified random sampling technique. A questionnaire was used as the research instrument in this study. Statistics used to analyze data included frequency, percentage, mean, standard deviation, and Pearson
Product Moment Correlation. The level of statistical significance was set at 0.01 .

\section{Research Results and Discussion.}

7.1. The sample group revealed that the good governance administration of $\mathrm{Na}$ Yai Arm SubDistrict Administrative Organization was of a high level. The findings were consistent with Santhad (2008) who studied citizens' opinions on good governance of Ban Pae Sub-District Administrative Organization, Khu Mueang district, Buriram province. He found that the citizens' opinions on good governance were also at a high level. The reason why good governance of Na Yai Arm SubDistrict Administrative Organization is at a high level is because staff comply with the rule of law and regulations.In addition, the level of moral realization in staff has led to there being no fraud in the organization. They have achieved a good strategy for transparency management by disclosure of the results of all public works. Furthermore,they promote citizens' participation in development activities. 
7.2. The sample group revealed that service quality at $\mathrm{Na}$ Yai Arm Sub-District Administrative Organization was also of a high level. This result is consistent with the findings of Rochana (2010) which found that service quality of Sam Pra Ya Sub-District Administrative Organization, Cha-Am district, Phetchaburi province, was of a similarly high level. The reason service quality of The Na Yai Arm SubDistrict Administrative Organization achieved a high level is because of high achievement in three aspects of service quality, including empathy, responsiveness, and reliability of service respectively. Empathy was shown in that access to service is available to all citizens and in particular, service waiting time is low at the organization. Responsiveness was shown by a consistent improvement of services which meet the needs of citizens. Furthermore, in terms of reliability of service, effective service have been provided

as well as improvements in tools, equipment and technology in the workplace to increase effectiveness. 7.3. There was a linear relationship between good governance administration and service quality at $\mathrm{Na}$ Yai Arm Sub-District Administrative Organization. It was a positive, high relationship. The relationship between good governance and service quality was because Na Yai Arm Sub-District Administrative Organization has been implementing and reforming according to good governance principles consisting of: Rule of law, morality, transparency, participation, accountability, and cost-effectiveness bringing about good quality of service. Good service quality responds to the needs of citizens who live in $\mathrm{Na}$ Yai Arm Sub-District Administrative Organization.

\section{Recommendations}

8.1. Policy Recommendation: The research study found that the perception of good governance of transparency had the lowest average; therefore $\mathrm{Na}$ Yai Arm Sub-District Administrative Organization should promote a policy of transparency to improve work performance.

8.2. Recommendations for implementation: $\mathrm{Na}$ Yai Arm Sub-District Administrative Organization should have a head of department to help provide a document service for disabled people and create a suggestion box to involve citizens and receive complaints and suggestions.

8.3. Recommendations for further study. Further study should be conducted on the relationship between good governance and service quality of $\mathrm{Na}$ Yai Arm Sub-District Administrative Organization by using qualitative research to achieve more specific data.

\section{References}

(1) Chaleamphol Srihong.(1999). Research Methodology. n.p.

(2) Christopher Hood. (1991). "A Public Management for All Seasons?" Public Administration.

(3) Crosby, P. B. (1979). Quality is Free. New York: McGraw-Hill.

(4) Good Governance (2013). Retrieved August 20,2013, fromhttp://library2.parliament.go.th/library/cont ent_law/30.pdf

(5) Parasuraman A., Zeithaml V. A. \& Berry, L. L. (1988). SERVQUAL: A Multiple Item Scale for Measuring Customer Perceptions of Service Quality. Journal of Retailing, 64 (Spring), pp. $12-40$. 
(6) Rochana Phumala .(2010) . Service quality of Sam Pra Ya Sub-District Administrative

(7) Organization, Cha-Am district, Phetchaburi province. Master Degree thesis, Public Administration, Sukhothai Thammathirat University.

(8) Santhad Siebthaisong (2008).The citizen opinion to the good governance of

(9) Ban Pae Sub-District Administrative Organization, Khu Mueang district, Buriram Province. Master Degree thesis, Public Administration, Rajabhat Buriram University

(10) Yamane, Taro. (1973). Statistics : an introductory analysis. New York: Harper and Row.Yash. 